https://doi.org/10.30910/turkjans.680048

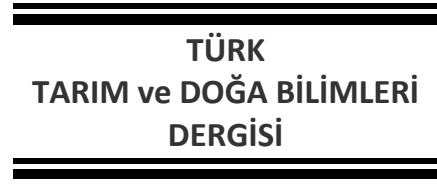

TÜRK

DERGISI

\section{Research Article}

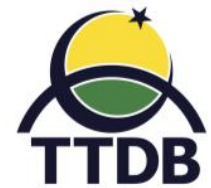

www.dergipark.gov.tr/turkjans

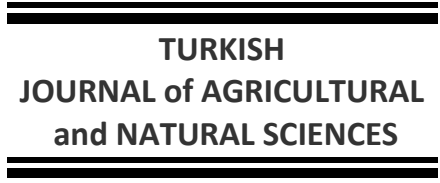

OURNAL Of AGRICULTURA
and NATURAL SCIENCES

Improving Silage Feed Quality of Maize Intercropped with Some Legumes

Mustafa KIZILŞIMŞEK*, Tuğba GÜNAYDIN, Ahmet ASLAN, Kübra KEKLiK, Hamit AÇIKGÖZ

Kahramanmaras Sutcu Imam Univ., Faculty of Agric. Field Crops Dept. Kahramanmaras, Turkey

*Corresponding author: mkizil@ksu.edu.tr

Received: 20.11.2019

Received in Revised: 12.12 .2019

Accepted: 16.12 .2019

\begin{abstract}
Maize is the most cultivated plant for silage making in all over the World due to its many advantages such as producing high yield, suitable for mechanization and easy to ensile. However, the most important shortcoming property of maize silage is insufficiency of protein content. This study was planned for resolving this problem to a certain extent by growing maize with legume in the field as intercrop without any decrease in maize stand. Silage $\mathrm{pH}$ was significantly decreased in all intercropping patterns, regardless to legume, compared to sole maize, however, all $\mathrm{pH}$ values were enough low indicating a sufficient fermentation has occurred in the silo. Intercropping maize with soybean increased dry matter recovery (DMR), dry matter intake (DMI) and relative feed value (RFV) compared to sole crop maize. The NDF values of intercropped maize were better than that of pure maize resulting increases in DMI. Intercropping maize with any legumes caused an increase in crude protein (CP) content.
\end{abstract}

Key words: Silage, feed quality, dry matter recovery, corn.

\title{
Mısır ve Bazı Baklagillerin Birlikte Üretimi ile Silaj Yem Kalitesini Artırma Olanakları
}

\begin{abstract}
Özet
Mısır bitkisi yüksek verimliliği, mekanizasyona uygunluğu ve silolanmasının kolay olması gibi birçok avantajları nedeniyle dünyanın her yerinde silaj amacıyla en fazla yetiştirilen bitkidir. Bununla birlikte, mısır bitkisinin en önemli dezavantajı, yetersiz protein içeriğidir. Bu çalışma, mısır bitki sıklığını azaltmadan, karışım halinde bazı baklagil bitkilerini (maş fasülyesi, sırık fasülye, börülce ve soya) de yetiştirerek, bu sorunu belli ölçüde çözmek amacıyla yapılmıştır. Çalışmada saf mısır ve karışımlar, Kahramanmaraş Sütçü İmam Üniversitesi Ziraat Fakültesi deneme alanında yetiştirilmiştir. Araştırma sonucunda, baklagil bitki türüne bakılmaksızın tüm birlikte üretim sistemlerinde silaj pH değerinin saf mısıra göre önemli derecede arttığı, bununla birlikte, tüm pH değerlerinin silo içerisinde iyi bir fermentasyonu işaret edecek şekilde yeteri kadar düştüğü görülmüştür. Mısırın soya fasulyesi ile birlikte yetiştirilmesinin, saf mısıra göre, kuru madde korunumunu, kuru madde tüketimini ve oransal yem değerini artırdığı belirlenmiştir. Birlikte üretimden elde edilen NDF değerlerinin saf mısır değerlerine göre daha düşük olduğu ve kuru madde tüketimini olumlu etkilediği belirlenmiştir. Mısır bitkisini herhangi bir baklagil ile birlikte yetiştirmenin ham protein içeriğinde artışlara neden olduğu saptanmıştır.
\end{abstract}

Anahtar kelimeler: Silaj, yem kalitesi, kuru madde korunumu, mısır.

\section{Introduction}

The main problem in animal husbandry especially in developing countries is generally related to animal feeding activities. In many case, quantity and quality of feed is not enough for ruminants. Many growers produce their ruminant feed by their own due to economical and quality concern. Maize is the most popular crop for making silage, which plays a vital role as a winter feed in the livestock industries (Geren et al., 2008) for many countries including Turkey (Kizilsimsek et al., 2016). Maize crop can produce high yield in a 
single cut (Serbester et al., 2015) and is easy to ensile due to its water soluble carbohydrate (WSC) content. It also has high energy value as ruminant feed (Stoltz et al., 2013; Geren et al., 2008). However, the most important handicap of maize is definitely its low crude protein (CP) content that is around $6-7 \%$ of its dry matter (DM) base. Legume plants, which can grow on summer period like maize, could be a good solution for dealing with this problem due to their high protein content, which is over $15 \%$ in many cases. Intercropping legumes with maize may not only improve yield and quality of feed but also may limit the use of fertilizer, herbicides and insecticides, which are heavily used in monoculture for high yield anxiety (Dawo et al., 2007). Growing maize with a legume may be advantageous for effective using ecological sources such as soil nutrients and light as well as preventing erosion. It is also known that maize is the dominant component crop in determining the yield compared to legumes in intercrop. So not decreasing maize plant density in intercrop may be a good way in order to keep high silage yield produced.

The fact remains that; there have been many studies that individual crop of any intercrop systems were sown or harvested at different time points (Stoltz et al., 2013). However, this is not applicable for practice for silage production system. In silage making, the individual crops of intercropping system should be sown and harvested simultaneously (Stoltz et al., 2013) in order to avoid high cost and to get a good fermentation for both component crops. There are many studies on intercropping systems of maize with soybean (Carruthers et al., 2000; Martin et al., 1998; Serbester et al., 2015), cowpea (Geren et al., 2008; Azim et al., 2000) and bean species (Nurk et al., 2017; Dawo et al., 2007; Armstrong et al., 2008; Stoltz et al., 2013) individually however the studies on comparing legumes are very limited.

The main objective of this study was to improve feed quality by increasing feed CP content and reducing dry matter recovery (DMR) of maize silage by intercropping maize with mung bean, pole bean, cowpea or soybean and harvest simultaneously without decreasing maize plant density in intercrops compared to its sole stand for producing high yield.

\section{Material and Methods}

Sole maize and legume intercrops were grown during the main crop season in the summer period of 2019 at the research station of Agriculture Faculty, Kahramanmaras Sutcu Imam University, Turkey. The field experiment was designed as completely randomized blocks design with three replications. In the experiment, maize plant density in intercrop systems were the same as maize sole stand while legume density in intercrop was $33 \%$ of what they should be in their sole systems. Maize were sown on $15 \mathrm{~cm}$ depart on the row and $70 \mathrm{~cm}$ between rows. Only one legume seed was planted in between two maize on the row, so maize and legume plant number per unit area were the same. The plants were sown on $10^{\text {th }}$ May and harvested when the milk line reached to $2 / 3$ of the grain at $15^{\text {th }}$ August. Individual crops in intercrop systems were harvested together at the same time, chopped theoretically $2-4 \mathrm{~cm}$ length and ensiled by using plastic vacuum packed. The plastic packed was filled $500 \mathrm{~g} \pm 50 \mathrm{~g}$ with there parallel for all replications. The initial DM content of all silage were determined by taking 100 $\mathrm{g}$ of chopped samples and dried in an air forced oven at $78{ }^{\circ} \mathrm{C}$ for 48 hours. Silages were opened after 60 days of ensiling on $15^{\text {th }}$ October and analyzed for $\mathrm{pH}$, dry matter (DM), neutral detergent fiber (NDF), acid detergent fiber (ADF) and crude protein $(C P)$. Forages were sampled for all parcels around $50 \mathrm{~g}$ and dried at $78{ }^{\circ} \mathrm{C}$ for 48 hours for determining initial DM content $\left(T_{0}=\right.$ Time Zero) of feed before ensiling. Resulted silage samples were also dried at $78{ }^{\circ} \mathrm{C}$ for 48 hours for determining the $D M\left(T_{60}=\right.$ Time 60 days) then the samples were ground to pass through $1 \mathrm{~mm}$ screen. Dry matter recovery (DMR) was calculated by dividing $D M T_{60}$ to $D M T_{0}$ and multiplying by 100. The $\mathrm{N}$ content of silage was determined by using Kjeldahl method then CP was calculated by multiplying $\mathrm{N}$ values with 6.25 coefficient. NDF and ADF were determined by using Ancom Fiber Analyser according to Van Soest et al. (1991). In order to have an idea about feed quality, digestible dry matter (DDM), dry matter intake (DMI) and relative feed value (RFV) were calculated.

The variance analysis of the data was made according to randomized blocks parcel design by using SAS software. The differences among the mean values were grouped by using the least significant difference (LSD) test.

\section{Results and Discussion \\ Dry matter contents, dry matter recovery and $\mathrm{pH}$} values

The mean values and statistical groups of initial DM content (DM $\mathrm{T}_{0}$ ), DM content of resulting silage (DM $\left(T_{60}\right)$, DMR and silage $\mathrm{pH}$ were given at Table 1. Silage $T_{0} D M$ content were higher in sole maize than those of maize intercropped with any legumes and the differences were significant only between sole maize and maize intercropped with soybean. Legumes were caused declining in DM content of silages, in variable levels depending on 
the legume species in intercrop, compared to sole crop maize silage. DM content of maize+soybean intercrop silage were $4.07 \%$ lower than that of sole maize silage due to late maturation of soybean compared to maize crop. Azim et al., (2000) have explained that silage DM content was decreased in intercrop maize with cowpea compared to sole maize silage. They also found that the DM content of silages decreased as the proportion of legume in intercrop increased. Similarly, Nurk et Al. (2017) stressed that DM concentration of silage decreased significantly with increasing bean contribution in silage and suggested that it is necessary to determine the right proportion of legumes in intercrop with maize in order to achieve a good fermentation. There were some contradictory results in literature related to DM content changes between sole and intercropped maize. For example, Sloltz et al., (2013), indicated that DM content of maize+faba bean intercrop silage was higher than that of sole maize silage regardless of nitrogen fertilization. Similarly, Serbester et al., (2015), found that, DM content of maize intercropped with soybean is variable depending on intercropping systems and harvest time. The DM contents of all applications of present study were in the range of optimum values, which was explained by McDonald et al. (1987) as 28 and $32 \%$, for a good fermentation. There were no significant differences among DM contents of $T_{60}$ silages. Armstrong et al. (2008) pointed that DM contents were not affected in legume and maize intercropping when legume proportion in the mixture is low.

Table 1. Dry matter in fresh material (DM T0) and dry matter (DM T60), dry matter recovery (DMR) and pH values of resulting silage.

\begin{tabular}{lcccc}
\hline Intercropping & DMT0 & DMT60 & DMR & pH \\
\hline Sole Maize & $33.88 \mathrm{a}$ & 31.37 & $92.57 \mathrm{ab}$ & $3.78 \mathrm{~d}$ \\
Maize Mung Bean & $33.52 \mathrm{ab}$ & 32.01 & $95.43 \mathrm{a}$ & $3.97 \mathrm{~b}$ \\
Maize Climbing Bean & $33.37 \mathrm{ab}$ & 30.25 & $90.67 \mathrm{~b}$ & $3.88 \mathrm{c}$ \\
Maize Cowpea & $33.48 \mathrm{ab}$ & 32.03 & $95.68 \mathrm{a}$ & $3.91 \mathrm{c}$ \\
Maize Soybean & $32.50 \mathrm{~b}$ & 31.28 & $96.19 \mathrm{a}$ & $4.07 \mathrm{a}$ \\
Mean & 33.35 & 31.39 & 94.11 & 3.92 \\
LSD $_{(0.05)}$ & 1.33 & n.s. & 4.32 & 0.06 \\
\hline
\end{tabular}

There were significant differences among DMR values, which were changed from 90.67 to 96.19\%. Mung bean, cowpea and soybean intercropping, except for climbing bean, with maize improved DMR compared to that of sole maize silage.

It can be speculated that all silages fermented well when $\mathrm{pH}$ values were taken into consider which were within the range of 3.8-4.2 for a good fermentation. Sole maize had the lowest $\mathrm{pH}$ value that is statistically significant compared to all intercropping systems probably due to its higher soluble carbohydrate contents. Geren et al. (2008), concluded that silage $\mathrm{pH}$ values were increased when maize was intercropped with cowpea or bean compared to sole crop maize silage. However, Stoltz et al., (2013), stressed that there were no significant differences between sole or intercropped maize in terms of $\mathrm{pH}$ values.

\section{Silage quality and feed value}

The differences in NDF contents of silages were statistically significant. All legume and maize intercropping systems had lower NDF contents than that of sole crop maize silage. In the present study, even though the differences were not significant, the ADF values as well as NDF in intercropping systems were reduced. Our findings were similar to Costa et al. (2012) who reported that there is usually lower concentration of cell wall fibers in legumes compared to cereals. Also, Nurk et al. (2017) emphasized that NDF concentration of maize as a cereal plant was higher than common bean as a legume. Serbester et al., (2015) concluded that silage NDF content in DM was decreased depending on the increase in soybean rate in mixture with maize. Accordingly, Javanmard et al., (2009) and Sanchez et al., (2010) also stressed decreasing values of NDF in mixed silage of maize and legumes such as soybean, vetch, berseem clover and common bean compared to maize silage alone. They also reported that NDF concentrations were variable from one to another ecology. However, Stoltz et al. (2013) found higher NDF contents in faba bean and maize intercropping silage than sole crop maize silage. Nurk et al. (2016) reported that there were no consistent differences in ADF content of maize silage when they ensiled alone or mixture with bean, accordingly to the present study.

The CP contents of all intercropping silages were higher than that of sole crop maize silage. Intercropping maize with even a low rate of legumes at planting increased CP level around $7.51-17.65 \%$ compared to sole maize silage. Geren et al. (2008) reported that CP contents of mixture 
increased noticeably in mixtures compared to maize alone. Stoltz et al (2013) mentioned an increase in CP content of maize silage when it was ensiled as mixture with faba bean. Carruthers et al. (2000) and Martin et al. (1990) stated higher CP content for maize and soybean intercrop silage than for pure maize silage. Putnam et al. (1986) and Serbester et al. (2015) also reported increased $\mathrm{CP}$ concentration for soybean and maize intercrop silage than sole maize silage. Accordingly,
Armstrong et al. (2008) indicated that CP concentrations were greater in corn intercropped with the lablab bean and velvet bean compared to corn monoculture.

Silage DDM values were not affected by intercropping systems. However, DMI and RFV values were significantly affected by adding legumes in maize silage. All mixture silage had grater DMI and RFV values compared to pure maize silage.

Table 2. Cell wall components (NDF, ADF), crude protein (CP) digestible dry matter (DDM), dry matter intake (DMI) and relative feed value (RFV) of resulting silage.

\begin{tabular}{lcccccc}
\hline \multicolumn{1}{c}{ Intercropping } & NDF & ADF & CP & DDM & DMI & RFV \\
\hline Sole Maize & $54.82 \mathrm{a}$ & 28.82 & $6.16 \mathrm{c}$ & 66.45 & $2.19 \mathrm{~b}$ & $112.81 \mathrm{c}$ \\
Maize Mung Bean & $53.46 \mathrm{ab}$ & 30.70 & $6.66 \mathrm{abc}$ & 64.98 & $2.25 \mathrm{ab}$ & $113.12 \mathrm{c}$ \\
Maize Climbing Bean & $51.89 \mathrm{ab}$ & 30.07 & $7.15 \mathrm{ab}$ & 65.48 & $2.31 \mathrm{ab}$ & $117.41 \mathrm{~b}$ \\
Maize Cowpea & $50.47 \mathrm{~b}$ & 28.26 & $6.51 \mathrm{bc}$ & 66.89 & $2.38 \mathrm{a}$ & $123.75 \mathrm{a}$ \\
Maize Soybean & $50.33 \mathrm{~b}$ & 29.89 & $7.48 \mathrm{a}$ & 65.62 & $2.39 \mathrm{a}$ & $121.52 \mathrm{a}$ \\
Mean & 52.19 & 29.55 & 6.88 & 54.08 & 2.30 & 117.72 \\
LSD $_{(0.05)}$ & 3.28 & n.s. & 0.86 & n.s. & 0.15 & 3.83 \\
\hline
\end{tabular}

\section{Conclusions}

Intercropping maize with legumes has many advantageous in silage feed quality. Growing legumes in maize stands even at a low rate could improve silage quality in terms of DMR, NDF content, DDM rate, DMI and especially CP concentrations. As result of these impacts, animal feed intake could improve and feed value could be increased markedly.

\section{References}

Armstrong, K.L., Albrecht, K.A., Lauer, J.G. 2008. Intercropping corn with lablab bean, velvet bean, and scarlet runner bean for forage. Crop Sci 48(1): 371-379.

Azim., A., Khan, A.G., Nadeem, M.A., Muhammad, D. 2000. Influence of Maize and Cowpea Intercropping on Fodder Production and Characteristics of Silage. Asian Australasian Journal of Animal Sciences 13(6): 781-784.

Carruthers, K., Prithiviraj, B., Cloutier, Q., Fe. D., Martin, R.C., Smith, D. L. 2000. Intercropping of Corn with Soybean\ Lupin and Forages] Silage Yield and Quality. J. Agronomy and Crop Science 074\066-074.

Costa, P.M., Villela, S.D.J., Leonel, F.D.P., Araújo, K.G., Ruas, J.R.M., Coelho, F.S., Andrade, V.R. 2012. Intercropping of corn, brachiaria grass and leguminous plants: productivity, quality and composition of silages. Rev. Bras. Zootecn. 41:2144-2149.

Dawo, M.I., Wilkinson, J.M., Sanders, F.E.T., Pilbeam, D.J. 2007. The yield and quality of fresh and ensiled plant material from intercropped maize (Zea mays) and beans
(Phaseolus vulgaris). Journal of Food and Agriculture. 87:1391-1399.

Geren, H., Avcioglu, R., Soya, H., Kır, B. 2008. Intercropping of corn with cowpea and bean: Biomass yield and silage quality. African Journal of Biotechnology. 7(22):4100-4104.

Javanmard, A., Nasab, A.D.M., Javanshir, A., Moghaddam, M., Janmohammadi, H. 2009. Forage yield and quality in intercropping of maize with different legumes as double cropped. J Food Agric Environ 7:163-166.

Kizilsimsek, M., Mokhtari, N.E.P., Erol, An., Öztürk, Ç., Gürkan, L. 2016. Laktik asit üretme yeteneklerinin yüksek olduğu bilinen izolatların mısır silajının in vitro gaz üretim değerleri ve yem kalitesi özelliklerine etkileri. Tarla Bitkileri Merkez Araştırma Enstitüsü Dergisi. 25 (Ozel sayı-2): 285-288.

Martin, R.C., Voldeng, H.C., Smith, D.L. 1990. Intercropping corn and soybean in a cool temperate region. Yield, protein and economic benefits. Field Crops Res. 12:184209.

Martin, R.C., Aststkie, T., Cooper, J.M. 1998. The effect of soybean variety on corn-soybean intercrop biomass and protein yields. Canadian Journal of Plant Science 78(2):289294.

Nurk, L., Graß, R., Pekrun, C., Wachendorf, M. 2017. Methane Yield and Feed Quality Parameters of Mixed Silages from Maize (Zea mays L.) and Common Bean (Phaseolus vulgaris L.). Bioeng. Res. 10:64-73.

Putnam, D.H., Herbert, S.J., Vargas, A. 1986. 
Intercropped corn-soyabean density studies. II. Yield composition and protein. Exp. Agric.11:262-270.

Sánchez R.G.D., Silva, J.T.E., Gil, A.P., Corona, J.S.S., Wong, J.A.C., Mascorron, A. 2010. Forage yield and quality of intercropped corn and soybean in narrow strips. Span J Agric Res 8:713-721.

Serbester, U., Akkaya, M.R., Yucel, C., Gorgulu, M. 2015. Comparison of yield, nutritive value and in vitro digestibility of monocrop and intercropped corn-soybean silages cut at two maturity stages. Italian Journal of Animal Science. 14:66-71.

Stoltz, E., Nadaeu, E., Wallenhammar, A.C. 2013. Intercropping maize and faba bean for silage under Swedish climate conditions. Agric. Res. 2 (1):90-97.

Van Soest, P.J., Robertson, J.D., Lewis, B.A. 1991. Methods for dietary fibre, neutral detergent fibre and non-starch polysaccharides in relation to animal Nutrition. Journal of Dairy Science 74: 3583-3597. 